
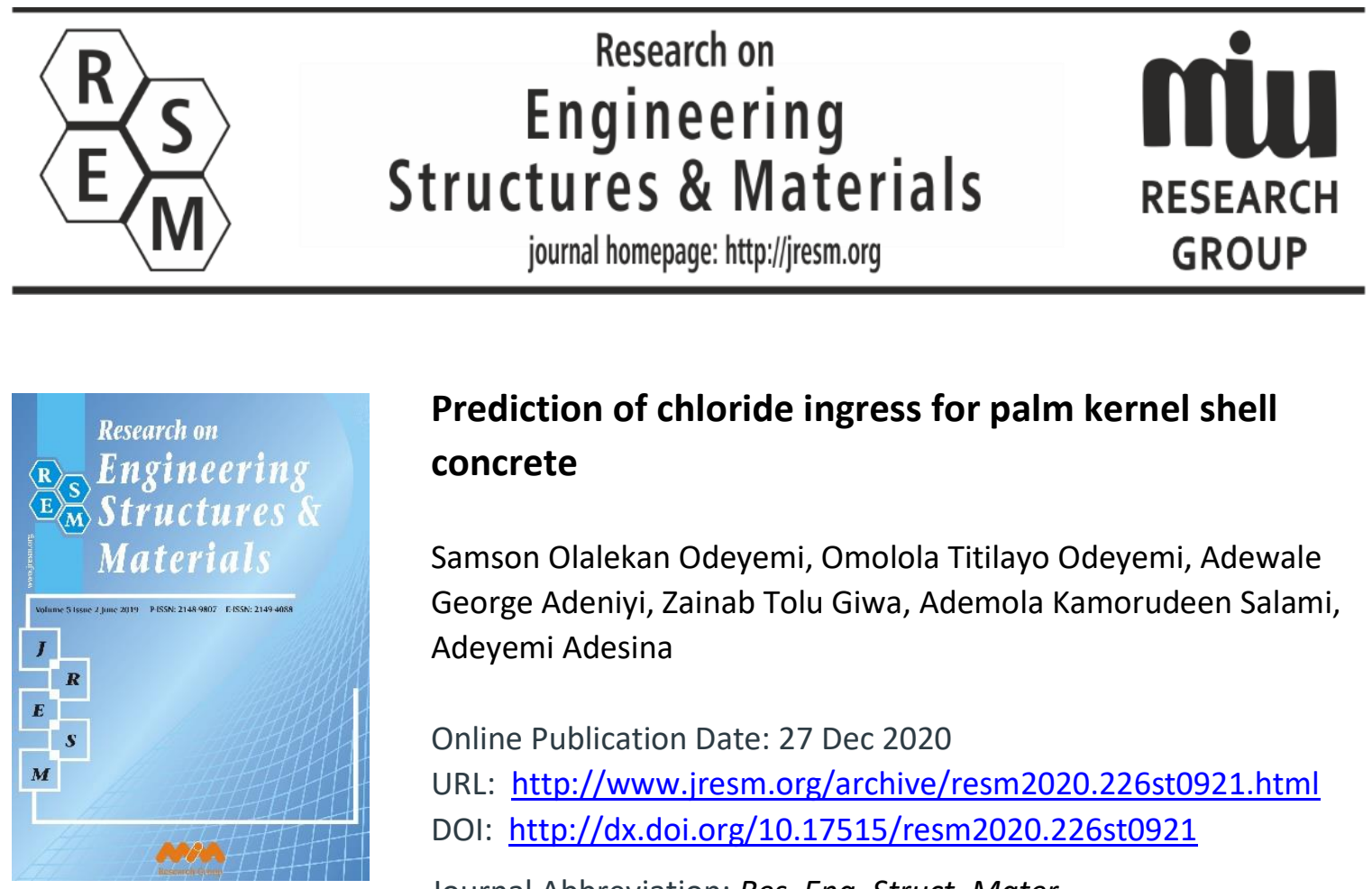

\title{
Prediction of chloride ingress for palm kernel shell concrete
}

Samson Olalekan Odeyemi, Omolola Titilayo Odeyemi, Adewale George Adeniyi, Zainab Tolu Giwa, Ademola Kamorudeen Salami, Adeyemi Adesina

Online Publication Date: 27 Dec 2020

URL: http://www.jresm.org/archive/resm2020.226st0921.html

DOI: http://dx.doi.org/10.17515/resm2020.226st0921

Journal Abbreviation: Res. Eng. Struct. Mater.

\section{To cite this article}

Odeyemi S O, Odeyemi O T, Adeniyi A G, Giwa Z T, Salami A K, Adesina A. Prediction of chloride ingress for palm kernel shell concrete. Res. Eng. Struct. Mater., 2021; 7(1): 35-49.

\section{Disclaimer}

All the opinions and statements expressed in the papers are on the responsibility of author(s) and are not to be regarded as those of the journal of Research on Engineering Structures and Materials (RESM) organization or related parties. The publishers make no warranty, explicit or implied, or make any representation with respect to the contents of any article will be complete or accurate or up to date. The accuracy of any instructions, equations, or other information should be independently verified. The publisher and related parties shall not be liable for any loss, actions, claims, proceedings, demand or costs or damages whatsoever or howsoever caused arising directly or indirectly in connection with use of the information given in the journal or related means.

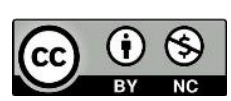

Published articles are freely available to users under the terms of Creative Commons Attribution - NonCommercial 4.0 International Public License, as currently displayed at here (the "CC BY - NC"). 


\title{
Research on Engineering Structures \& Materials
}

journal homepage: http://jresm.org

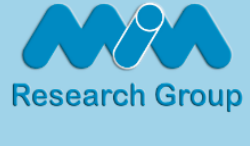

Research Article

\section{Prediction of chloride ingress for palm kernel shell concrete}

\author{
Samson Olalekan Odeyemi ${ }^{* 1, a}$, Omolola Titilayo Odeyemi ${ }^{2, b}$, Adewale George \\ Adeniyi $^{3, c}$, Zainab Tolu Giwa ${ }^{1, d}$, Ademola Kamorudeen Salami1,e, Adeyemi Adesina ${ }^{4, f}$ \\ ${ }^{1}$ Department of Civil \& Environmental Engineering, Kwara State University Malete, Nigeria \\ ${ }^{2}$ Department of Science Laboratory Technology, Kwara State Polytechnic, Ilorin, Nigeria \\ ${ }^{3}$ Department of Chemical Engineering, University of Ilorin, Ilorin, Nigeria \\ ${ }^{4}$ Department of Civil Engineering, University of Windsor, Canada
}

\begin{tabular}{|c|c|}
\hline Article Info & Abstract \\
\hline $\begin{array}{l}\text { Article history: } \\
\text { Received } 21 \text { Oct } 2020 \\
\text { Revised } 14 \text { Dec } 2020 \\
\text { Accepted } 27 \text { Dec } 2020\end{array}$ & $\begin{array}{l}\text { Steel reinforcement corrosion emanating from ingress of chloride into concrete } \\
\text { is the key reason for weakening of concrete structures globally. Infiltration of } \\
\text { chloride into concrete happens by absorption and diffusion. On the other hand, } \\
\text { reinforced concrete containing supplementary materials is more susceptible to } \\
\text { corrosion exposure due to its high permeability. In this paper two }\end{array}$ \\
\hline $\begin{array}{l}\text { Keywords: } \\
\text { Palm Kernel Shell; } \\
\text { Chloride ingress; } \\
\text { Concrete; } \\
\text { Coarse aggregate; } \\
\text { Corrosion; } \\
\text { Chloride }\end{array}$ & $\begin{array}{l}\text { concentrations of sodium chloride ( } \mathrm{NaCl} \text { ) were applied on concrete containing } \\
\text { palm kernel shell as full replacement to granite. Concrete cube specimens of } \\
\text { Grade } 20 \text { were cast into } 150 \mathrm{~mm} \text { by } 150 \mathrm{~mm} \text { by } 150 \mathrm{~mm} \text { moulds, and their } \\
\text { workability were determined by compacting factor and slump tests. The } \\
\text { hardened specimens were soaked in sodium chloride }(\mathrm{NaCl}) \text { solution of } 3 \% \text { and } \\
6 \% \text { concentration. Spray, Absorption and Compressive strength tests were } \\
\text { conducted at } 7,14,21 \text { and } 28 \text { days. Equations were generated by means of the } \\
\text { data gotten from the laboratory tests to forecast the chloride penetration depth } \\
\text { into the palm kernel shell concrete under the conditions considered in this work. } \\
\text { The models generated revealed that absorption affected chloride ingress into the } \\
\text { concrete significantly at } 6 \% \mathrm{NaCl} \text { concentration. The models also reveal that the } \\
\text { cover to reinforcements in Palm Kernel Shell Concrete subjected to chloride } \\
\text { attack should be more than what is presently endorsed for reinforced concrete } \\
\text { structures. }\end{array}$ \\
\hline
\end{tabular}

(C) 2021 MIM Research Group. All rights reserved.

\section{Introduction}

A key material often utilized in the building industry is concrete [1-5]. Utilizing Palm Kernel Shells (PKS) as a substitute for coarse aggregates in concrete can reduce the rising price of materials used in construction especially in less developed nations of the world and also bring about a reduction in the overall dead weight of the building. Olutoge (2000) [6] examined the physical, compressive strength and fire resistance of concrete made with PKS and the strength fell within the range specified for lightweight concrete.

Itam et. al [7] studied the density of PKS concrete and found out that it varies in the range of 1700 to $2050 \mathrm{~kg} / \mathrm{m}^{3}$ based on the type of sand used and the PKS contents. Generally, when concrete's density is lower than $2000 \mathrm{~kg} / \mathrm{m}^{3}$, it is categorized as lightweight concrete. Thus, PKS concrete is classified as lightweight concrete [8].

Reinforced concrete (RC) is a composite in which concrete's little tensile strength and ductility are enhanced by the addition of steel reinforcements which have higher tensile

\footnotetext{
*Corresponding author: samson.odeyemi@kwasu.edu.ng

a https://orcid.org/0000-0001-5217-3403; b https://orcid.org/0000-0003-4832-885X;

c https://orcid.org/0000-0001-6615-5361; d https://orcid.org/0000-0002-4447-2240;

ehttps://orcid.org/0000-0003-4787-2618; ${ }^{\text {f }}$ https://orcid.org/0000-0002-7602-3896

DOI: http://dx.doi.org/10.17515/resm2020.226st0921
}

Res. Eng. Struct. Mat. Vol. 7 Iss. 1 (2021) 35-49 
strength [3]. The steel reinforcements are often entrenched in concrete before the setting of such concrete. The reinforcing arrangements are designed to counteract tensile stresses in regions of the concrete that might cause cracking and subsequently lead to structural failure. RC structures are intended to stay safe and functional over a long period of time. For example, bridges are generally designed to stay safe and functional for a service life of 120 years [9]. However, when these structures are constructed in environments that are high in chloride concentration, the steel reinforcements in them are prone to corrosion from the chloride ions. This poses a challenge to these structures leading to grave economic and safety implications. $\mathrm{NaCl}$ is an ionic compound and it is composed of the same amounts of positively and negatively charged sodium and chloride ions respectively [10].

When concrete structures are constructed in highly chloride concentrated environments, chloride ions have the capacity of penetrating through concrete cover into the reinforcing steel $[9,11-14]$. Corrosion is initiated on the steel at the critical concentration of the chlorides with adequate oxygen and moisture. Corrosion has two implications on the reinforcements: it results in spalling, cracking, and delamination of the concrete leading to the weakening of the bond between the concrete and the reinforcement. Also, this further makes it possible for the chloride ions to infiltrate the steel to cause further corrosion. Additionally, the area of the reinforcement reduces as they corrode, with a resulting reduction in their capacity to carry load [15-18]. Steel corrosion affects structural performance by reducing the effective cross-sectional area of reinforcements, its yield and ultimate strength, elongation rate, bond strength between the steel and concrete, thereby reducing the stiffness and bearing capacity of the structure. These have grave impact on the environment $[9,19,20]$. Fig. 1 shows the effect of chloride ingress on some steel samples as reported by Adeniyi et. al [11].
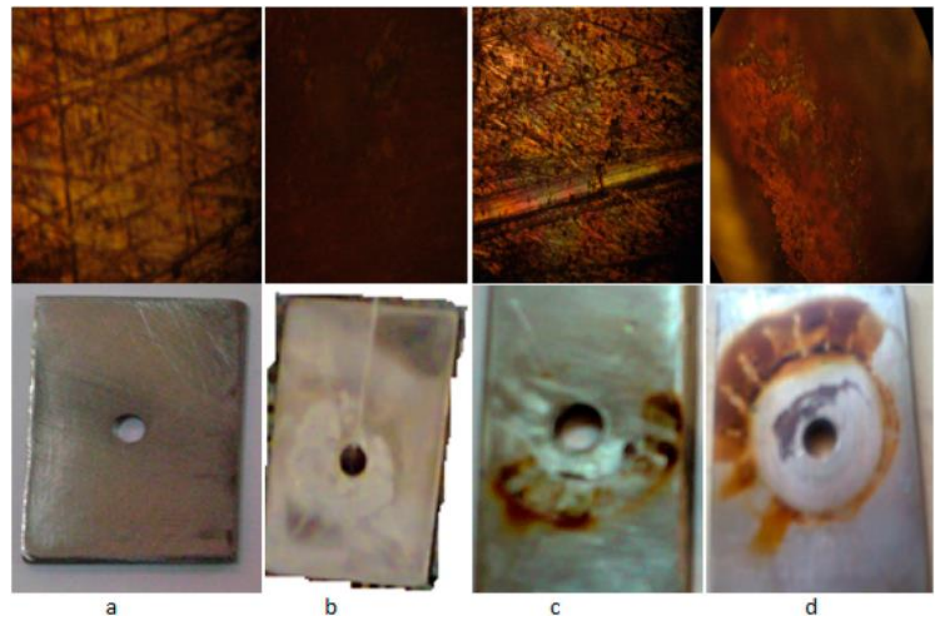

Fig. 1 Photographs and optical micrographs of SS-304 in different chloride environments, (a) as received (b) freshwater (c) brackish and (d) marine after 60 days of immersion [11]

The conveyance of chloride ions into concrete in chloride infested environments can occur by capillary absorption, diffusion and hydrostatic pressure. Absorption occurs by the rising of water in the concrete and this largely affect the level at which chloride ion is taken up. Thus, it impacts the gradient concentration in the concrete. Once there is continuous hydration of the concrete, diffusion process then increases the access of chloride ions through the cover. Permeation arises by water pressure when chloride ion solution is present under an applied hydraulic head on at least a side of the concrete structure 
$[17,21,22]$. Consequently, movement of chloride ions via absorption and pore-liquid, when solutions with chloride ions are sucked into concrete pores, are the two major conveyance mechanisms for chloride ingress in concrete. Diffusion, which is a slow and continuous process, occurs as a result of chloride concentration gradient, once the pore liquid is not allowed evaporate $[9,17]$.

PKS are components of oil palm tree and are predominant in western Africa especially in the riverine areas of Nigeria [23]. They are often regarded as wastes and discarded in the open consequently constituting a nuisance in the environment with little economic benefits. Odeyemi et. al (2019) [3], Dadzie and Yankah (2015) [24] and Olutoge (2010) [25] all stated that the incorporation of PKS in concrete will result in a substantial decrease in the cost of concrete production. The government of Nigeria is promoting the use of local materials in construction to lessen cost. This has resulted in the sourcing and development of substitutes such as non-conventional and agro-based construction materials to achieve the optimum benefits of agricultural wastes [26]. PKS are fibrous carbonaceous and are found in various sizes ranging from $0-5 \mathrm{~mm}, 5-10 \mathrm{~mm}$, and $10-15 \mathrm{~mm}$ for small, medium, and large sizes respectively [3]. Fig. 2 shows some samples of PKS.

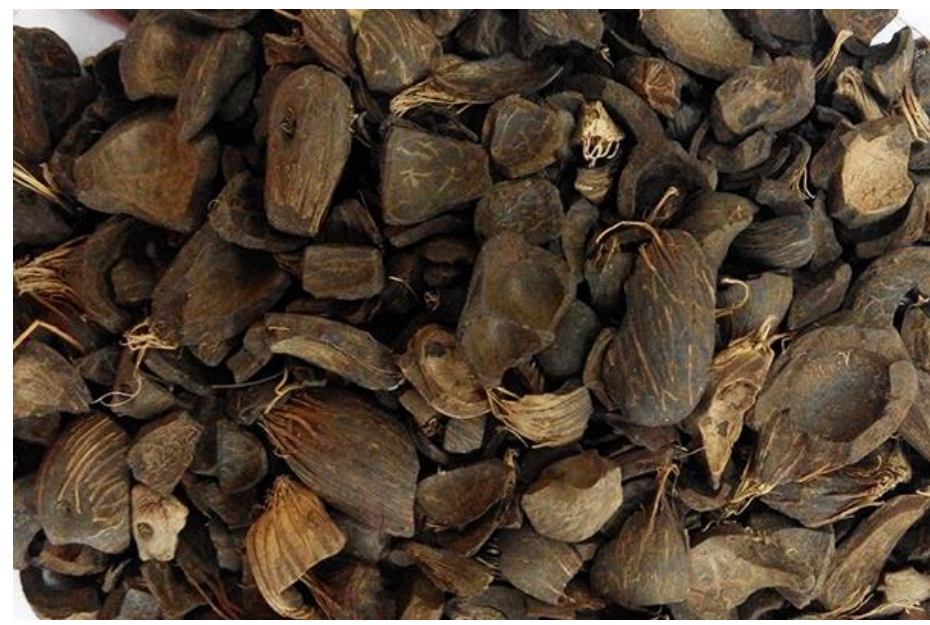

Fig. 2 Samples of Palm Kernel Shell

The permeability of PKS concrete is high when compared to normal concrete as reported by [27-29] leading to a decline in its durability when exposed to moisture. Therefore, the use of PKS in reinforced concrete structures may lead to early reinforcement corrosion in chloride environment. Therefore, the objectives of this research are: to evaluate the compressive strengths of palm kernel shell concrete when subjected to chloride attack, to determine the consequence of chloride ingress in PKS concrete and to generate numerical models for predicting chloride penetration due to absorption on two different $\mathrm{NaCl}$ concentrations.

\section{Research Methodology}

\subsection{Materials}

Materials utilized for this research include Lafarge Elephant brand of Ordinary Portland Cement (Grade 42.5R), Palm Kernel Shell (PKS) obtained from local palm oil industry within Ibadan, Oyo State was used as coarse aggregate. River sand was used as the fine aggregate which conforms to BS EN 12620:2002+A1:2008 [30], potable (drinking) water of $\mathrm{pH} 7$ and Sodium chloride $(\mathrm{NaCl})$ solution which was utilized as the curing medium to 
determine the chloride ingress into the concrete. Epoxy resin was employed to coat the concrete to foil evaporation loss and to guarantee that ingress of salt solution is in a single direction. Silver Nitrate $\left(\mathrm{AgNO}_{3}\right)$ having a concentration of $0.1 \mathrm{M}$ was utilized as the colorimetric solution to estimate the chloride penetration depth.

\subsection{Method}

\subsubsection{Laboratory Tests}

Particle Size Distribution as stipulated in BS EN 933-1:2012 [31] , Specific Gravity and Aggregate Crushing Value tests were conducted on the aggregates, while Slump and Compacting factor tests, both conforming to [32] and [33] respectively, were conducted on the concrete in its fresh state. The proportion of aggregates going through the sieves was plotted against the diameter of the aggregates. Equation 1 was used to compute the Fineness modulus and the Uniformity coefficient, which expresses the grading of the aggregate, was determined from the graph by means of Equation 2.

$$
\begin{aligned}
& \text { Fineness modulus }=\frac{\text { Total cummulative percentage retained }}{100} \\
& C_{u}=\frac{D_{60}}{D_{10}}
\end{aligned}
$$

where: $C_{u}$ represents the Uniformity coefficient, $D_{60}$ denotes the size of aggregates corresponding to $60 \%$ fines on the cumulative particle-size distribution curve and $D_{10}$ denotes the size of aggregates corresponding to $10 \%$ fines on the cumulative particle-size distribution curve. If the $C_{u}$ of the sample is lower than 4.0 it is inferred that the sample is uniformly graded but if the $C_{u}$ of the sample is larger than 4.0, then it is inferred that the sample is well graded $[15,34,35]$. Also, destructive Compression test which conforms to [36] as shown in Fig. 3 and Chloride penetration evaluation were carried out on hardened concrete.

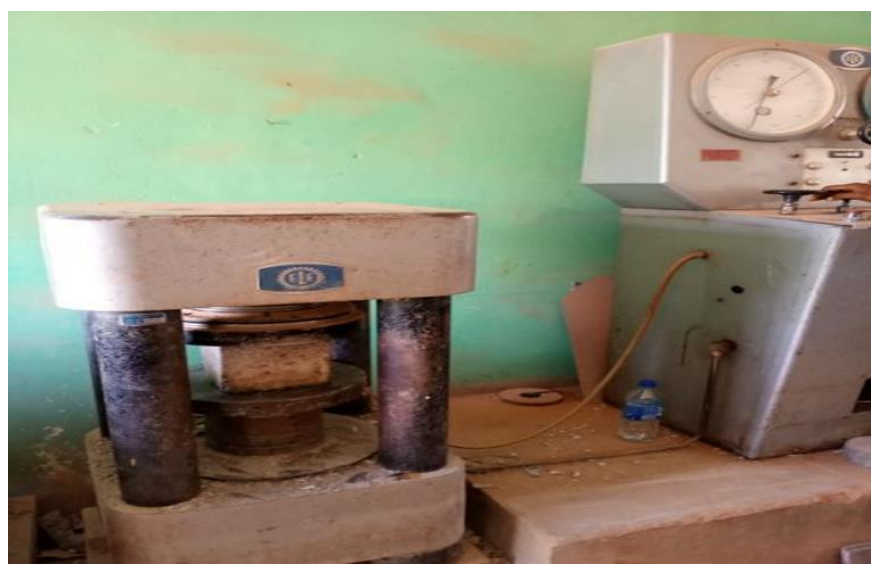

Fig. 3 Destructive Compression Test on Concrete Samples 


\subsubsection{Concrete Batch, Mixing and Curing}

A mix ratio of 1:2:4 for a compressive strength Grade 20 was used, and batching was carried out by weight adopting a water-cement ratio of 0.5 . Mixing was done manually as shown in Fig. 4. The specimens were compacted in three different layers; each layer compacted with twenty-five (25) blows with the aid of a tamping rod. The surface of each of the samples was trowel finished to be flat with the top of the concrete mould. The samples were left for 24 hours to ensure setting of the concrete cubes and they were demoulded thereafter. Three cubes from each group were randomly chosen and weighed before immersing in water. This was done to determine the weight gained by each group after each curing regime. The cubes were divided into two groups for curing, that is, curing with clean water and curing with salt water both at $3 \%$ and $6 \%$ concentration. Curing by immersion was adopted for all the concrete cubes as shown in Fig. 5. The first groups of concrete cube samples were cured in clean water for a period of 28 days so that they can attain their full compressive strength. The weight gained after this time was recorded for each group.
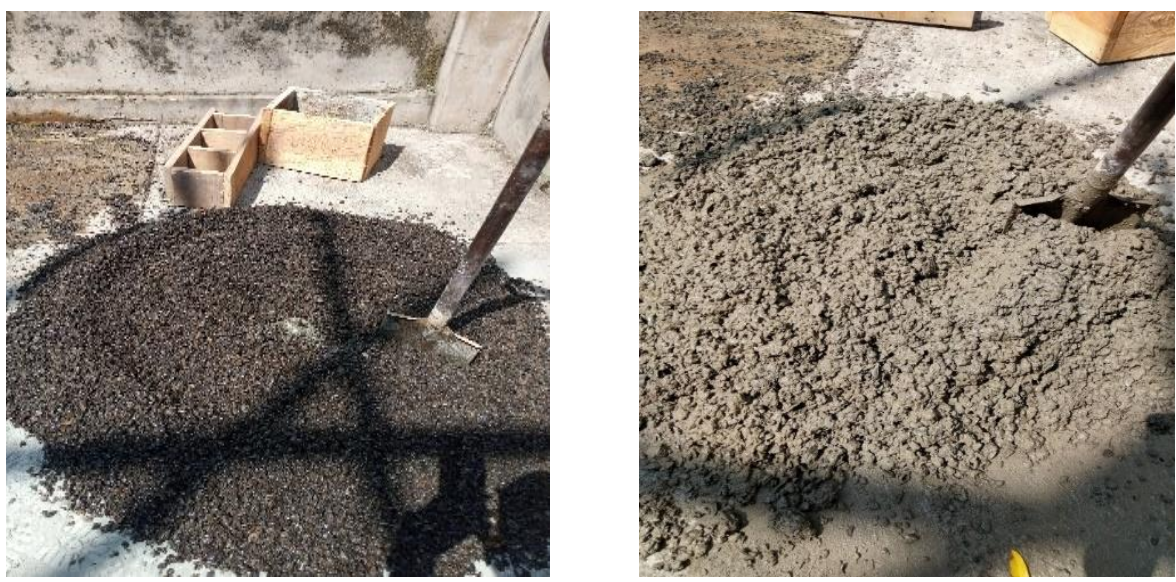

Fig. 4 Mixing of Palm Kernel Shell Concrete

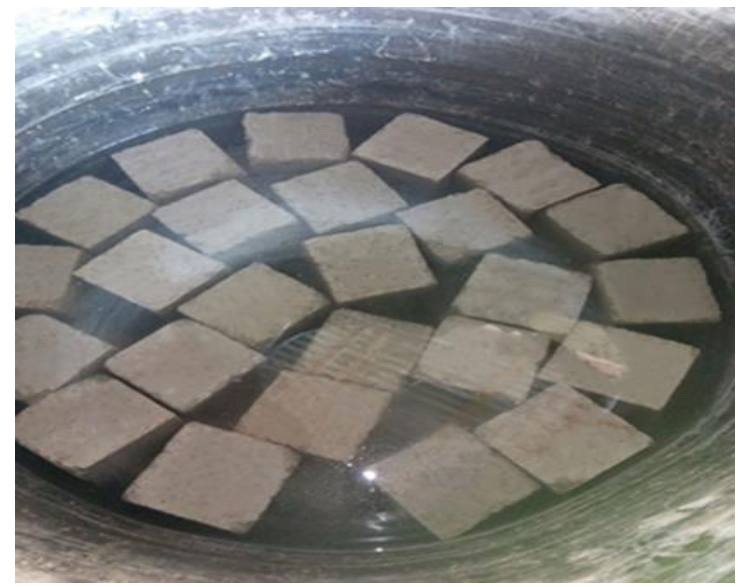

Fig. 5 Curing of Concrete Cubes 


\subsubsection{Chloride Penetration Test on Concrete}

The four (4) sides of the second group of samples were treated with epoxy resin. The epoxy resin was applied on the specimens to prevent the loss of water from the sides and to guarantee salt solution is one-directional. Afterwards, the samples were allowed to cure by the drying of the epoxy resin. The concrete cube specimens were then submerged in $\mathrm{NaCl}$ solution with a concentration of $3 \%$ and $6 \% \mathrm{NaCl}$ respectively and left in the salt solution for 7, 14, 21 and 28 days as specified by BS 1881-122 [37] in order to generate data for the model.

After each curing time, the specimens were split vertically, and the vertical surface was sprayed with the colorimetric solution and allowed to stay for 5 minutes. This test was done to obtain the depth of chloride penetration using the colorimetric solution. The colorimetric solution used in this research is Silver Nitrate $\left(\mathrm{AgNO}_{3}\right)$ solution having a concentration of $0.1 \mathrm{M}$. The colour of the chloride-contaminated zone changed to light grey colour. The chloride penetration depth was gotten with the aid of a venier caliper. The colour change agrees with the submission by [38], who also discovered that the duration of colour change is a function of the reaction between chloride and $\mathrm{AgNO}_{3}$ on the sprayed surface, to evaluate the depth of chloride penetration.

The model for the chloride ingress in the PKS concrete was generated based on the experimental data obtained from the tests conducted using SPSS software package. The parameters utilized for the model formulation are compressive strength $\left(f_{c u}\right)$, time $(t)$, absorption $(i)$ and chloride penetration depth $(d)$. The chloride penetration depth was then stated as a function of compressive strength, time and absorption i.e. $d=f\left(f_{c u}, t, i\right)$.

\section{Results and Discussions}

\subsection{Properties of Aggregates}

The graph of the sieve analysis conducted on the fine aggregates is presented in Fig. 6. The size of the aggregate varies from $0.10 \mathrm{~mm}$ to $4.75 \mathrm{~mm}$ signifying that the samples are within the group of fine, medium and little coarse sand [15]. This result is within the range specified for fine aggregates. The coefficient of uniformity $\left(C_{u}\right)$ is 1.8 which is less than 4 indicating that the fine aggregate is uniformly graded.

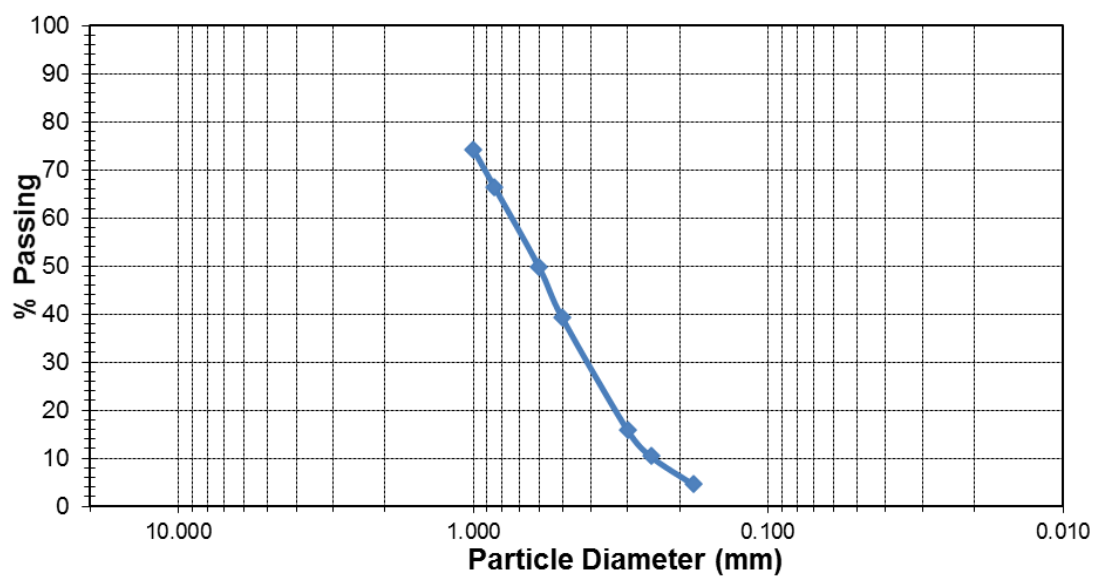

Fig. 6 Particle size distribution (PSD) curve of the fine aggregate 
ACI Education Bulletin (2007) [39] specified that Specific gravity for aggregates should be within 2.30 to 2.90 . The specific gravity for the fine aggregates in this study is 2.65 . This signifies that the fine aggregates are suitable for construction purpose.

The ACV for the coarse aggregate used in this study is $29.8 \%$ which is in the range prescribed by BS EN 12620:2002+A1:2008 [30]. This denotes that the aggregate is fit to produce concrete.

\subsection{Workability of Fresh Concrete}

Compacting factor and slump test were utilized in determining the workability of the fresh concrete. From the test carried out, a compacting factor of 0.98 and slump height of $45 \mathrm{~mm}$ was obtained. The result implies that the concrete is stiff. The results are consistent with the submission of Azunna (2019) [27], Anifowose et. al (2017) [40], Ede et. al (2016) [41] and Bamigboye et. al (2015) [42].

\subsection{Compressive Strength}

The results for the compressive strength test for the cubes cured with water, $3 \% \mathrm{NaCl}, 6 \%$ $\mathrm{NaCl}$ for 7, 14, 21 and 28 days are presented in Fig. 7. The Figure revealed that samples cured in ordinary potable water has the maximum compressive strength at 28 days compared to the one cured in salt water. The Figure also reveals that the compressive strengths of concrete cubes cured in salt water reduced as the curing days increases. However, concrete cubes cured with $3 \% \mathrm{NaCl}$ retained its compressive strength when exposed to the salt solution better than the samples in the $6 \% \mathrm{NaCl}$ solution. The compressive strength results obtained in this research is in tandem with the result obtained by Azunna (2019) [27] and Odeyemi et. al (2019) [3] for PKS concrete.

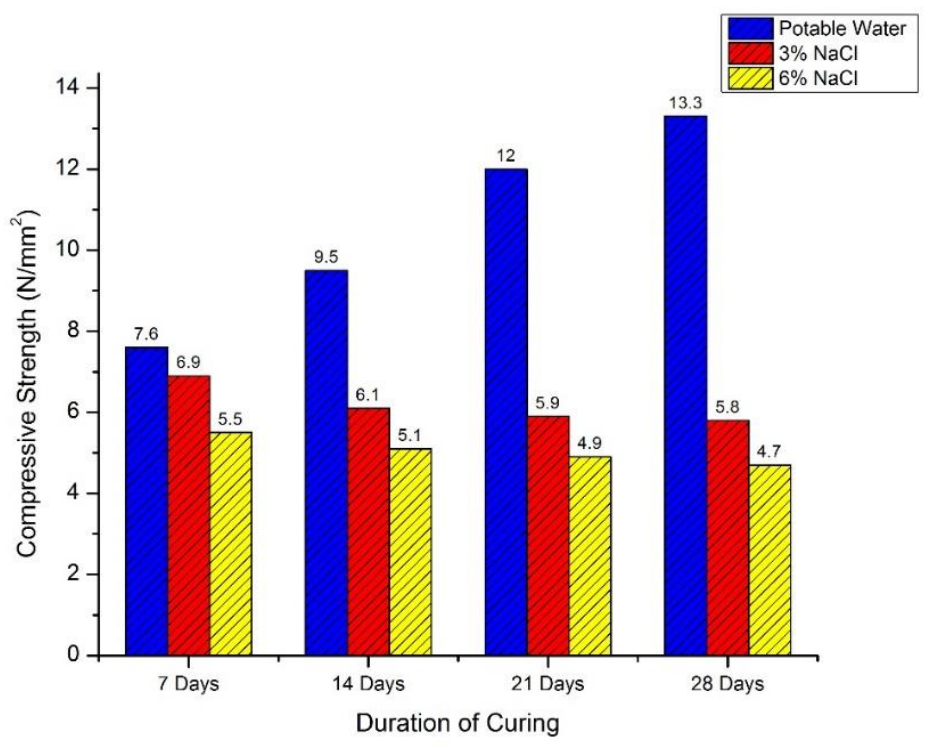

Fig. 7 Average Compressive strength of Concrete Cubes 


\subsection{Water Absorption}

Fig. 8 is a presentation of the result of the Absorption tests conducted on concrete cubes at $7,14,21$ and 28 days in ordinary potable water, $3 \% \mathrm{NaCl}$ and $6 \% \mathrm{NaCl}$ solutions. The results show that the chloride concentration of the curing medium increases the water absorption capacity of the concrete cubes. Thus, the samples cured in $6 \% \mathrm{NaCl}$ solution absorbed more water and salt when compared with other samples. This result is consistent with the findings of Ikumapayi (2019) [9].

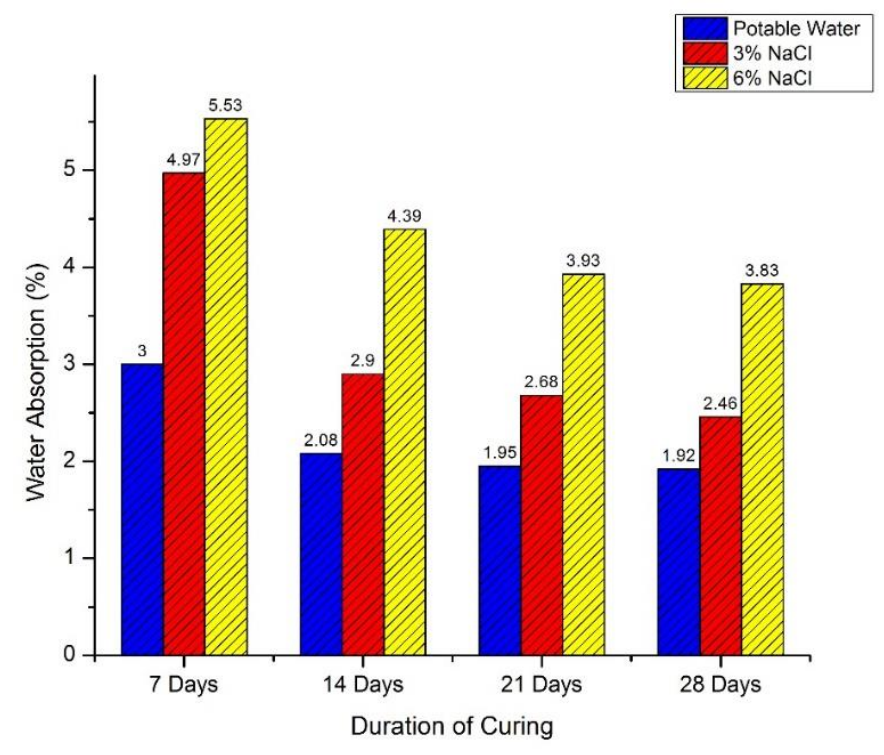

Fig. 8 Water Absorption for concrete cured with water and sodium chloride

\subsection{Depth of Chloride Penetration}

Fig. 9 illustrates the result of the spray test conducted to determine chloride penetration depth on the PKS concrete at 7, 14, 21 and 28 days respectively in sodium chloride solution. It was discovered that as the curing days increase, the depth of chloride penetration also increases. This happened since the depth of chloride penetration is a function of the available pore space in the sample and the concentration of the salt solution. The result shows that concrete cubes cured in $6 \%$ saltwater have the highest penetration.

\subsection{Model for Chloride Penetration Depth}

\subsubsection{Sodium chloride (3\% $\mathrm{NaCl}$ )}

Tables 1, 2, 3 and 4 show the analysis and results of data gotten from tests conducted on the $3 \% \mathrm{NaCl}$ solution. The regressions analysis gave an $\mathrm{R}^{2}$ value of 0.940 which is an indication that there is a good relationship between the chloride penetration depth $(d)$ and other parameters i.e. Absorption $(i)$, Time $(t)$ and Compressive strength $\left(f_{c u}\right)$. 


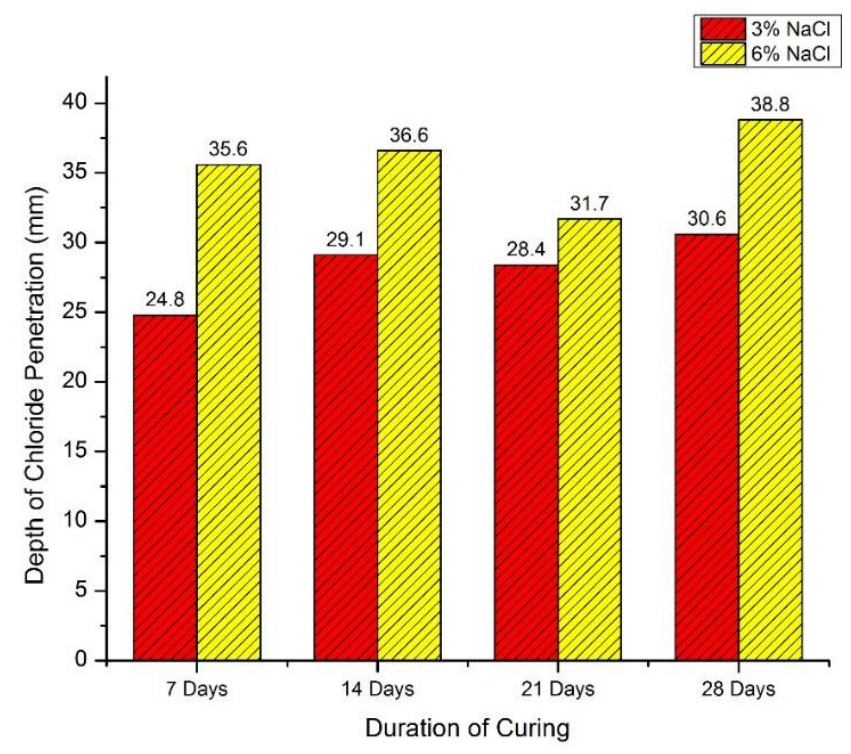

Fig. 9 Depth of chloride penetration in concrete

The level of significance of the values obtained from Table 2 is less than 0.05 which shows that the regression coefficients are statistically significant. Thus, the model for chloride penetration for concrete immersed in 3\% Sodium Chloride solution is presented in Equation 3

$$
d=27.776+1.682 t+0.19 f_{c u}-1.036 i
$$

Where $\mathrm{d}=$ Chloride penetration depth $(\mathrm{mm}) ; f_{c u}$ is the characteristic strength $\mathrm{N} / \mathrm{mm}^{2} ; t$ is Time (Age of Concrete coded in multiple of 7 i.e. 7 days $=1,14$ days $=2,21$ days $=3$ and 28 days $=4) ; i$ - Absorption.

Table 1 Model Summary for 3\% Sodium Chloride ( $\mathrm{NaCl}$ )

\begin{tabular}{ccccc}
\hline Model & $\mathrm{R}$ & R Square & Adjusted R Square & Std. Error of the Estimate \\
\hline 1. & 0.970 & 0.940 & 0.918 & 0.63882 \\
\hline
\end{tabular}

Table 2 Analysis of Variance

\begin{tabular}{cccccc}
\hline Model & Sum of Squares & df & Mean Square & f & Significance \\
\hline Regression & 51.238 & 3 & 17.079 & 41.852 & 0.000 \\
1 Residual & 3.265 & 8 & 0.408 & & \\
Total & 54.503 & 11 & & & \\
\hline
\end{tabular}


Table 3 Coefficients Summary for Sodium Chloride $\mathrm{NaCl}$ at 3\% Model

\begin{tabular}{|c|c|c|c|c|c|c|}
\hline & \multirow{2}{*}{ Model } & \multicolumn{2}{|c|}{$\begin{array}{l}\text { Unstandardized } \\
\text { Coefficients }\end{array}$} & \multirow{2}{*}{$\begin{array}{c}\begin{array}{c}\text { Standardized } \\
\text { Coefficients }\end{array} \\
\text { Beta }\end{array}$} & \multirow{2}{*}{$\mathrm{T}$} & \multirow{2}{*}{ Significance } \\
\hline & & B & $\begin{array}{l}\text { Standard } \\
\text { Error }\end{array}$ & & & \\
\hline \multirow{4}{*}{1} & Constant & 27.776 & 1.891 & & 14.686 & 0.000 \\
\hline & $\mathrm{t}$ & 1.682 & 0.188 & 0.882 & 8.925 & 0.000 \\
\hline & $f_{c u}$ & 0.091 & 0.263 & 0.035 & 0.346 & 0.738 \\
\hline & $\mathrm{i}$ & -1.036 & 0.220 & -0.423 & -4.698 & 0.002 \\
\hline
\end{tabular}

Table 4 Regression Summary for Chloride Depth Penetration and Absorption for 3\% $\mathrm{NaCl}$ Solution

\begin{tabular}{ccccccccc}
\hline & Coefficients & $\begin{array}{c}\text { Standard } \\
\text { Error }\end{array}$ & t Stat & P-value & $\begin{array}{c}\text { Lower } \\
95 \%\end{array}$ & $\begin{array}{c}\text { Upper } \\
95 \%\end{array}$ & $\begin{array}{c}\text { Lower } \\
95.0 \%\end{array}$ & $\begin{array}{c}\text { Upper } \\
95.0 \%\end{array}$ \\
\hline Intercept & 29.6328 & 5.21786 & 5.67910 & 0.00020 & 18.0066 & 41.25894 & 18.00667 & 41.25894 \\
\hline $\begin{array}{c}\text { Absorption } \\
\text { (\%) }\end{array}$ & 1.711101 & 1.22513 & 1.39666 & 0.19273 & -1.0187 & 4.440861 & -1.01866 & 4.440861 \\
\hline
\end{tabular}

Fig. 10 shows that there is no relationship between depths of sodium chloride penetration $\mathrm{NaCl}(3 \%)$ and Absorption for $\mathrm{NaCl}$. This show an approximately constant slope and the $\mathrm{R}^{2}$-value is very small which support the model result earlier obtained that it can only explain about $0 \%$ of the variation of the data, and also indicate that the depth penetration of sodium chloride do not really depend on the absorption of the salt solution.

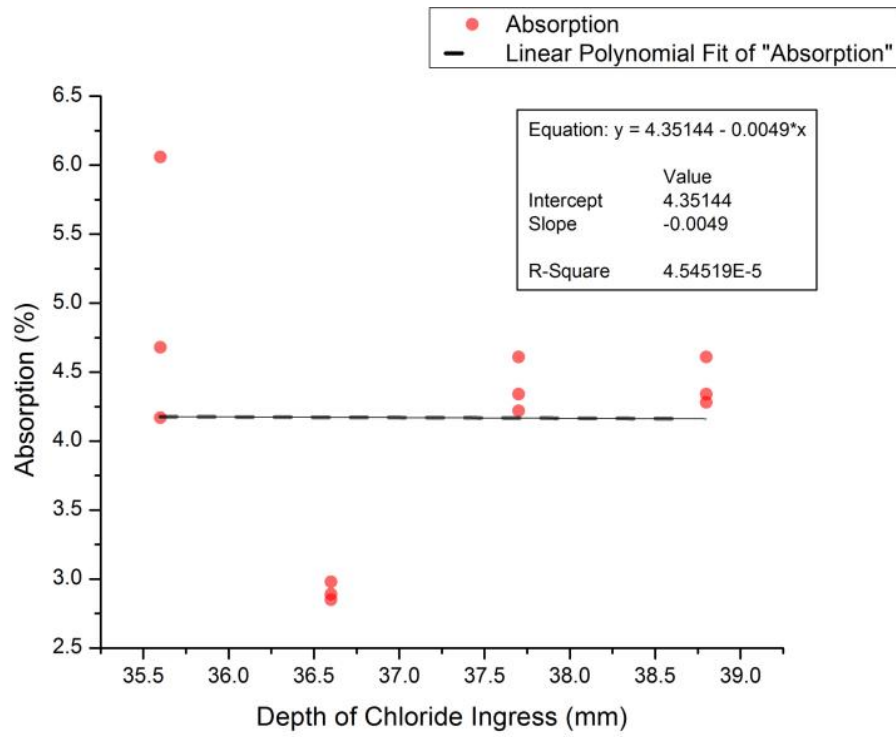

Fig. 10 Chloride Penetration depth against Absorption for $3 \% \mathrm{NaCl}$ 


\subsection{6\% Sodium chloride $(\mathrm{NaCl})$}

Table 5 presents the regression analysis showing the coefficient of correlation $\mathrm{R}^{2}$ value of 0.989 which implies that there is a high relationship between the chloride penetration depth $(d)$ and other parameters considered in the model absorption i.e. $(i)$, time $(t)$ and compressive strength $\left(f_{c u}\right)$. Table 6 shows that the regression coefficient is statistically significant. Also, Table 7 and 8 reveals that the significant value for the intercept and time is statistically significant while absorption and compressive strength are not. Thus, the model is presented in Equation 4

$$
d=34.462+1.073 t+0.19 f_{c u}+0.019 i
$$

Where $\mathrm{d}=$ chloride penetration depth (mm); $F_{c u}$ is the characteristic strength $N / \mathrm{mm}^{2} ; t$ is Time (Age of Concrete coded in multiple of 7 i.e. 7 days $=1,14$ days $=2,21$ days $=3$ and 28 days $=4) ; i$ - Absorption.

Table 5 Model Summary for 6\% Sodium Chloride ( $\mathrm{NaCl})$

\begin{tabular}{ccccc}
\hline Model & R & R Square & Adjusted R Square & Std. Error of the Estimate \\
\hline 2 & 1.000 & 0.989 & 0.973 & 0.03300 \\
\hline
\end{tabular}

Table 6 Analysis of Variance

\begin{tabular}{cccccc}
\hline Model & Sum of Squares & df & Mean Square & f & Sig \\
& & & & & \\
\hline Regression & 17.174 & 3 & 5.725 & 5258.253 & $0.000^{\mathrm{b}}$ \\
$\begin{array}{c}1 \text { Residual } \\
\text { Total }\end{array}$ & .009 & 8 & 0.001 & & \\
\hline
\end{tabular}

Table 7 Coefficients Summary for Sodium Chloride $\mathrm{NaCl}$ at 6\% Model

\begin{tabular}{|c|c|c|c|c|c|c|c|c|}
\hline & \multirow[t]{2}{*}{ Model } & \multicolumn{2}{|c|}{$\begin{array}{l}\text { Unstandardized } \\
\text { Coefficients }\end{array}$} & \multirow{2}{*}{$\begin{array}{c}\begin{array}{c}\text { Standardized } \\
\text { Coefficients }\end{array} \\
\text { Beta }\end{array}$} & \multirow[t]{2}{*}{$\mathrm{T}$} & \multirow[t]{2}{*}{ Significance } & \multicolumn{2}{|c|}{$\begin{array}{c}95.0 \% \\
\text { Confidence } \\
\text { Interval for B }\end{array}$} \\
\hline & & B & $\begin{array}{l}\text { Standard } \\
\text { Error }\end{array}$ & & & & $\begin{array}{l}\text { Lower } \\
\text { Bound }\end{array}$ & $\begin{array}{l}\text { Upper } \\
\text { Bound }\end{array}$ \\
\hline \multirow{4}{*}{2} & Constant & 34.462 & 0.084 & & 412.204 & 0.000 & 34.269 & 34.655 \\
\hline & $\mathrm{t}$ & 1.073 & 0.010 & 1.002 & 106.451 & 0.000 & 1.049 & 1.096 \\
\hline & $f_{c u}$ & 0.005 & 0.008 & 0.002 & 0.186 & 0.857 & -0.017 & 0.020 \\
\hline & $\mathrm{i}$ & 0.019 & 0.010 & 0.005 & 0.509 & 0.624 & -0.018 & 0.028 \\
\hline
\end{tabular}

Table 8 Regression Coefficient for Chloride Depth Penetration and Absorption for 6\% $\mathrm{NaCl}$ Solution

\begin{tabular}{ccccccccc}
\hline & Coefficients & $\begin{array}{c}\text { Standard } \\
\text { Error }\end{array}$ & t Stat & P-value & $\begin{array}{c}\text { Lower } \\
95 \%\end{array}$ & $\begin{array}{c}\text { Upper } \\
95 \%\end{array}$ & $\begin{array}{c}\text { Lower } \\
95.0 \%\end{array}$ & $\begin{array}{c}\text { Upper } \\
95.0 \%\end{array}$ \\
\hline $\begin{array}{c}\text { Intercept } \\
\text { Absorption } \\
(\%)\end{array}$ & 32.01836 & 3.61004 & 8.86923 & 0.0000472 & 23.9746 & 40.0620 & 23.974 & 40.005 \\
& 1.98375 & 0.75291 & -1.2933 & 0.2249 & -2.6513 & 0.7038 & -2.651 & 0.7844 \\
\hline
\end{tabular}


Fig. 11 shows that there is a linear relationship between sodium chloride penetration depth and Absorption for $6 \% \mathrm{NaCl}$ solution. This show an upward movement trend and the $\mathrm{R}^{2}$ value shows that the variation in the depth of penetration of sodium chloride can be explained at about $17 \%$ of its absorption.

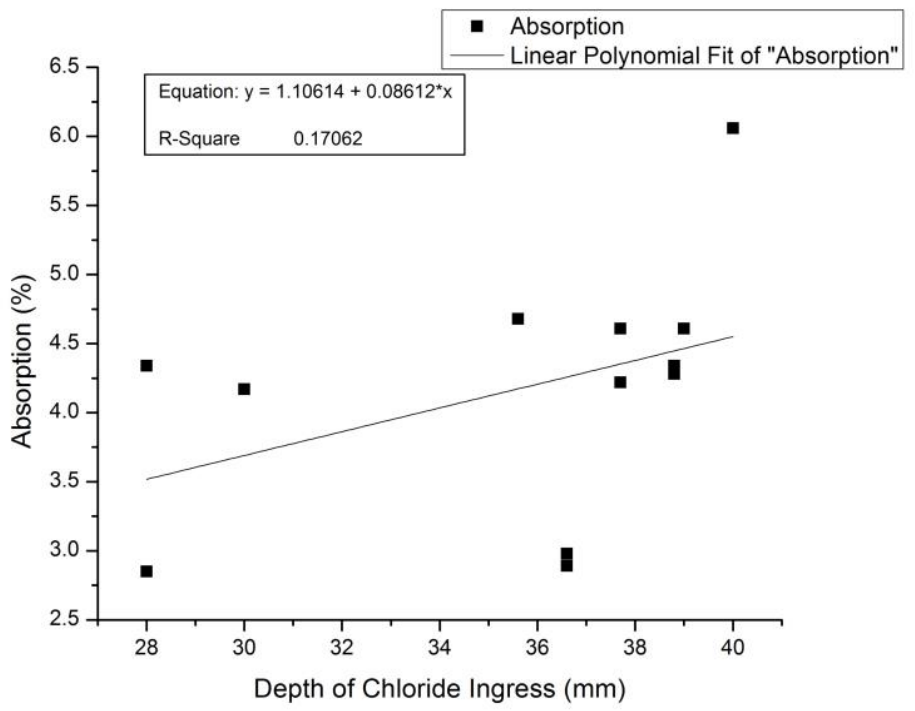

Fig. 11 Chloride Penetration depth against Absorption for 6\% $\mathrm{NaCl}$

\section{Conclusions}

Studies have shown that the corrosion of steel reinforcements resulting from chloride attack is a major cause of weakening of concrete structures globally. Chloride ingress into concrete takes place by absorption and diffusion. Researchers have also discovered that reinforced concrete containing supplementary materials are more susceptible to corrosion exposure due to their high permeability. This research investigated the effect of two concentrations of sodium chloride $(\mathrm{NaCl})$ on concrete containing palm kernel shell as full replacement of granite. Grade 20 concrete were cast into $150 \mathrm{~mm}$ by $150 \mathrm{~mm}$ by $150 \mathrm{~mm}$ cubic moulds, and their workability were determined by compacting factor and slump tests following the relevant international standards. The hardened concrete samples were fully submerged in potable water, sodium chloride $(\mathrm{NaCl})$ solution of $3 \%$ and $6 \%$ concentration, respectively. Spray, Absorption and Compressive strength tests were conducted at 7, 14, 21 and 28 days. Equations were generated by means of the data gotten from the laboratory tests to forecast the chloride penetration depth into the palm kernel shell concrete for the two (2) chloride concentrations considered in this work. The following conclusions were drawn from the study:

- The absorption of concrete cured in ordinary potable water (control) were found to be less than that of the concrete cured in salt water.

- Absorption, Time and Compressive Strength have a significant influence on the diffusion of chloride ions into the PKS concrete.

- The chloride penetration depth into the PKS concrete increases as the exposure days increases. 
- Exposure of PKS concrete to Sodium chloride $(\mathrm{NaCl})$ solution leads to a long-term loss in compressive strength.

- For the Grade 20 concrete utilized for this study, the relationship between chloride penetration depth, age of concrete, compressive strength and absorption is given as:

$$
\begin{array}{ll}
d=27.776+1.682 t+0.19 f_{c u}-1.036 i & \text { for } 3 \% \mathrm{NaCl} \text { concentration } \\
d=34.462+1.073 t+0.19 f_{c u}+0.019 i & \text { for } 6 \% \mathrm{NaCl} \text { concentration }
\end{array}
$$

\section{References}

[1] Mitchell J. The concrete conundrum. Chem World 2008.

[2] Odeyemi SO, Atoyebi OD, Ayo EK. Effect of Guinea Corn Husk Ash on the Mechanical Properties of Lateritic Concrete. IOP Conf Ser Earth Environ Sci 2020;445:1-11. https://doi.org/10.1088/1755-1315/445/1/012034

[3] Odeyemi SO, Abdulwahab R, Abdulsalam AA, Anifowose MA. Bond and Flexural Strength Characteristics of Partially Replaced Self-Compacting Palm Kernel Shell Concrete. Malaysian J Civ Eng 2019;31:1-7. https://doi.org/10.11113/mjce.v31n2.535

[4] Anifowose MA, Adeyemi A0, Odeyemi SO, Abdulwahab R, Mudashiru RB. Comparative study of Ikirun and Osogbo Slag on concrete grade 20. Niger J Technol 2019;38:283-8. https://doi.org/10.4314/njt.v38i2.2

[5] Klyuev SV, Klyuev AV., Abakarov AD, Shorstova ES, Gafarova NG. The effect of particulate reinforcement on strength and deformation characteristics of fine-grained concrete. Mag Civ Eng 2017;75:66-75.

[6] Olutoge FA. The production of concrete using palm kernel shell as a partial/full substitute for coarse aggregates. 2nd Eng. Conf. Sch. Eng. Technol. F.U.T. Minna, Niger State, Niger., 2000, p. 57-67.

[7] Itam Z, Beddu S, Mohd Kamal NL, Alam MA, Ayash UI. The Feasibility of Palm Kernel Shell as a Replacement for Coarse Aggregate in Lightweight Concrete. IOP Conf. Ser. Earth Environ. Sci., vol. 32, 2016. https://doi.org/10.1088/1755-1315/32/1/012040

[8] Oyejobi DO, Abdulkadir TS, Yusuf IT, Badiru MJ. Effects of Palm Kernel Shells Sizes and Mix Ratios on Lightweight Concrete. J Res Inf Civ Eng 2012;9.

[9] Ikumapayi CM. Development of a short time model for predicting chloride ingress into normal and pozzolanic concrete. IOP Conf Ser Mater Sci Eng 2019;640:1-13. https://doi.org/10.1088/1757-899X/640/1/012113

[10] Abalaka AE, Babalaga AD. Effects of Sodium Chloride Solutions on Compressive Strength Development of Concrete Containing Rice Husk Ash. ATBU J Environ Technol 2011;4:33-40.

[11] Adeniyi AG, Ogunleye 00, Durowoju MO, Odeyemi SO. Modelling stochastic response of type 304 stainless steel (SS-304) crevice corrosion in chloride environments. Indian Chem Eng 2018;0:1-10. doi:10.1080/00194506.2018.1548951. https://doi.org/10.1080/00194506.2018.1548951

[12] Ojoawo SO, Oladejo AM, Olaniyan OS. Effect of Chloride Contaminated Water on the Compressive Strength of Plain Concrete. IOSR J Mech Civ Eng 2014:99-108. https://doi.org/10.9790/1684-113499108

[13] Adeniyi AG, Ogunleye 00, Durowoju MO, Odeyemi SO. Damaging Profile of SS-304 Crevice Corrosion in Chloride Environments. ABUAD J Eng Res Dev 2019;2:11-9.

[14] Chalhoub C, François R, Carcasses M. Critical chloride threshold values as a function of cement type and steel surface condition. Cem Concr Res 2020;134. https://doi.org/10.1016/j.cemconres.2020.106086

[15] Neville AM. Properties of Concrete. 5th ed. Pearson Education Ltd; 2011. 
[16] Green WK. Steel reinforcement corrosion in concrete - an overview of some fundamentals. Corros Eng Sci Technol 2020:289-302. https://doi.org/10.1080/1478422X.2020.1746039

[17] Cao Q, Esmaily M, Liu RL, Birbilis N, Thomas S. Corrosion of mild steel under insulation - the effect of dissolved metal ions. Corros Eng Sci Technol 2020:322-30. https://doi.org/10.1080/1478422X.2020.1734737

[18] Cinitha A, Umesha PK, Iyer NR. An overview of corrosion and experimental studies on corroded mild steel compression members. KSCE J Civ Eng 2014;18:1735-1744. https://doi.org/10.1007/s12205-014-0362-0

[19] Zeng R, Zhang Y, Zhang X. Analysis on the Mechanical Properties of Corroded Reinforced Concrete. DEStech Trans Mater Sci Eng 2018:148-57. https://doi.org/10.12783/dtmse/msce2016/10462

[20] Yusoff M, Abdul Hamid NH, Arshad AK, Mohd Ridzuan AR, Awang H. InCIEC 2015 Proceedings of the International Civil and Infrastructure Engineering Conference. Springer, Singapore; 2015. https://doi.org/10.1007/978-981-10-0155-0

[21] Evans C, Richardson MG. Service Life of Chloride-Contaminated Concrete Structures. Concrete 2005:131-7.

[22] Andrade C. Linear propagation models of deterioration processes of concrete. Corros Eng Sci Technol 2020:283-8. https://doi.org/10.1080/1478422X.2020.1750161

[23] Oyedepo OJ, Olanitori LM, Akande SP. Performance of coconut shell ash and palm kernel shell ash as partial replacement for cement in concrete. J Build Mater Struct 2015;2:18-24.

[24] Dadzie DK, Yankah JE. Palm Kernel Shells as a partial replacement for Sand in Sandcrate block production. Chem Mater Res 2015;7:61-72.

[25] Olutoge FA. Investigations On Sawdust And Palm Kernel Shells As Aggregate Replacement. ARPN J Eng Appl Sci 2010;5:7-13.

[26] Mohammed H, Afolabi KO, Umoru LE. Crushed Palm Kernel Shell As a Partial Replacement of Fine Aggregate in Asphaltic Concrete. Int J Mater Methods Technol 2014;2:1-5.

[27] Azunna SU. Compressive strength of concrete with palm kernel shell as a partial replacement for coarse aggregate. SN Appl Sci 2019;1:1-10. https://doi.org/10.1007/s42452-019-0334-6

[28] Khankhaje E, Rafieizonooz M, Salim MR, Mirza J, Salmiati, Hussin MW. Comparing the effects of oil palm kernel shell and cockle shell on properties of pervious concrete pavement. Int J Pavement Res Technol 2017;10:383-92. doi:10.1016/j.ijprt.2017.05.003. https://doi.org/10.1016/j.ijprt.2017.05.003

[29] Eziefula UG, Opara HE, Anya CU. Mechanical Properties of Palm Kernel Shell Concrete in Comparison With Periwinkle Shell Concrete. Malaysian J Civ Eng 2017;29:1-14.

[30] BS EN 12620:2002+A1:2008. Specification for Aggregates from natural sources for concrete. British Standards, BSI Group Headquarters 389 Chiswick High Road, London, W4 4AL, UK, Standards Policy and Strategy Committee. 2008.

[31] BS EN 933-1. Tests for Geometrical Properties of Aggregates - Part 1: Determination of Particle Size Distribution - Sieving Method. 2012.

[32] BS EN 12350-2:2009. Testing Fresh Concrete - Slump Test, British Standards. 2009.

[33] BS 1881:103. Testing Concrete - Method for Determination of Compacting Factor, British Standards. 1983.

[34] Shetty MS. Concrete Technology Theory and Practice. S. CHAND \& Company Ltd., NewDelhi, India; 2008.

[35] Bowles JE. Foundation Analysis and Design. The McGraw-Hill Companies, Inc.; 1996.

[36] BS EN 12390-3:2009. Testing Hardened Concrete - Compressive Strength of Test Specimens, British Standards. 2009.

[37] BS 1881-122:2011. Testing concrete. Method for determination of water absorption. 2011. 
[38] Kim MY, Yang EI, Yi ST. Application of the colorimetric method to chloride diffusion evaluation in concrete structures. Constr Build Mater 2013. https://doi.org/10.1016/j.conbuildmat.2012.11.084

[39] ACI Education Bulletin. Aggregates for Concrete-Materials for Concrete Construction. Developed by Committee E-701, American Concrete Institute, 38800 Country Club Dr, Farmington Hills, Michigan, United States. 2007.

[40] Anifowose MA, Adebara SA, Odeyemi SO, Olahan AB, Aliyu T. Density, Workability And Compressive Strength Assessment Of Steel Slag In Concrete. Acta Tech Corviniensis Bull Eng 2017;10:63-7.

[41] Ede AN, Bamigboye GO, Olofinnade OM, Shittu KK. Influence of Portland cement brands and aggregates sizes on the compressive strength of normal concrete. Mater Sci Forum 2016;866:78-82. doi:10.4028/www.scientific.net/MSF.866.78. https://doi.org/10.4028/www.scientific.net/MSF.866.78

[42] Bamigboye GO, Ede AN, Egwuatu C, Jolayemi J, Olowu O. Assessment of Compressive Strength of Concrete Produced from Different Brands of Portland Cement. Civ Environ Res 2015;7:31-9. 